\title{
PENGARUH PIJAT PERINEUM SELAMA MASA KEHAMILAN TERHADAP RUPTURE PERINEUM DI PMB IDA IRIANI, S.SIT DAN PMB ERNIATI, AM.KEB KABUPATEN ACEH UTARA
}

\author{
Reva Afdila', Nurhapni Saragih ${ }^{2}$ \\ Program Studi Sarjana Kebidanan, STIKes Getsempena Lhoksukon \\ Reva.afdila08@gmail.com ${ }^{1}$, nurhapni.saragih@gmail.com²
}

\begin{abstract}
Perineal massage performed during pregnancy or 2 weeks before delivery, is useful for softening connective tissue, improving blood circulation, relaxation. This action will reduce the occurrence of perineal rupture, episiotomy and pain due to episiotomy sutures. The purpose of this study was to identify the effect of perineal massage during pregnancy on the incidence of perineal rupture in PMB Ida Iriani, S. Sit and PMB Erniati, Am.Keb, North Aceh Regency. Quasi-experiment research method intervention group and control group with a total sample of 36 respondents in each group. The sampling technique in this study was using non-probability sampling techniques. The results of the statistical test using the MannWhitney Upvalue test of 0.000, which means that there is an effect of perineal massage on perineal rupture. Suggestions for research sites can apply perineal massage during pregnancy to the incidence of perineal rupture.
\end{abstract}

Keywords $\quad$ : Perineal Massage, Perineal Rupture

\begin{abstract}
ABSTRAK
Pijat perineum merupakan tindakan yang akan mengurangi resiko terjadinya rupture perineum, episiotomi dan nyeri karena jahitan episiotomy. Resiko yang ditimbulkan karena robekan perineum adalah perdarahan, dengan perdarahan yang hebat, ibu akan mengalami kondisi tidak berdaya, lemah, anemia, dan berat badan menurun dan jika tidak mendapatkan pertolongan yang tepat dan cepat maka akan mengakibatkan kematian pada ibu. Tujuan penelitian untuk melihat Pengaruh Pijat Perineum Selama Masa Kehamilan Terhadap Kejadian Rupture Perineum di PMB Ida Iriani, S.Sit dan PMB Erniati, Am.Keb Kabupaten Aceh Utara. Metode penelitian quasi eksperimen kelompok intervensi dan kelompok kontrol dengan jumlah sampel masing-masing kelompok 36 responden. Hasil uji statistik menunjukan bahwa paritas ibu yang bersalin adalah primipara sebesar 16 (44,4\%). Hasil uji statistik dengan mengguanakn uji mann whitney p-value 0,000 yang berarti ada pengaruh pijat perineum terhadap rupturperineum. Saran bagi tempat penelitian dapat menerapkan pemijatan perineum selama masa kehamilan terdadap kejadian rupture perineum.
\end{abstract}

\section{Kata Kunci}

\section{PENDAHULUAN}

Persalinan adalah rangkaian proses yang berakhir dengan pengeluaran hasil konsepsi oleh ibu yang dimulai dengan kontraksi persalinan sejati yang ditandai perubahan progresif dari serviks dan diakhiri dengan pengeluaran plasenta. Atau persalinan adalah

\section{: Pijat Perineum, Ruptur Perineum}

proses pengeluaran hasil konsepsi berupa bayi yang dimulai dengan kontraksi, membuka, menipisnya serviks, serta janin turun kedalam jalan lahir (Savitri, 2015).

Menurut Survey di Indonesia yang di dapatkan data World Health Organization (WHO), kematian ibu paling banyak terjadi di Negara berkembang yaitu $99 \%$ di bandingkan negara maju. pada tahun 2015 adalah 239 per 
100.000 kelahiran hidup dan 12 per 100.000 kelahiran hidup di Negara maju sedangkan rasio angka kematian bayi sekitar 29 per 1000 kelahiraan hidup di Negara berkembang dan 5 per 1000 kelahiran hidup di Negara maju pada tahun 2015 (Singalingging \& Sikumbang, 2018).

Menurut Survey dari Aceh kematian ibuyang di sebabkan selama proses melahirkan baik yang normal maupun dengan tindakan, Jumlah kematian ibu sebanyak 239 orang. Komplikasi yang terjadi adalah perdarahan yang sering menyebabkan kefatalan/kematian bila tidak ditangani sesegera mungkin.

Menurut data Survey yang diperoleh dari Aceh Utara Jumlah kematian ibu sebanyak 10 orang (10\%). Komplikasi persalinan kala III dan IV merupakan masalah yang terjadi setelah janin lahir/berada diluar rahim. Komplikasi yang terjadi adalah perdarahan yang sering menyebabkan kefatalan/kematian bila tidak ditangani sesegera mungkin. Rupture perineum dapat disebabkan oleh beberapa faktor yaitu pengeluaran kepala yang mendadak dan cepat, ukuran bayi baru lahir yang berlebihan, dan jaringan ibu yang mudah robek (Dinkes Aceh Utara, 2018).

Menurut penelitian oleh Beckmann dan Garett tahun 2006. menunjukkan bahwa pijat perineum di usia 35 minggu kehamilan, dapat mengurangi kemungkinan trauma perineal yang membutuhkan jahitan. Umumnya wanita mengeluh kesakitan pada perineal di tiga bulan pasca kelahiran. Ibu-ibu yang rajin melakukan pijat perineum sejak 3 bulan sebelum hari-H persalinan, terbukti hampir tidak ada yang mengalami robekan perineum, kalaupun terjadi perobekan perineum secara alami, maka luka pulih dengan cepat. Wanita yang melakukan pijat perineum juga mengalami penurunan resiko dari trauma yang cukup berat dari episiotomi (Choirunissa \& Han, 2019).
Berdasarkan data yang diperoleh dari survey awal di PMB Ida Iriani, S.SiT pada tahun 2019 terdapat 1433 ibu hamil. Dimana jumlah ibu hamil trimester I (satu) 667 orang, jumlah ibu hamil trimester ke II (dua) 556 orang dan jumlah ibu hamil trimester ke III (tiga) 210 orang. Sedangkan tahun 2020 periode Januari s/d Mei 96 orang. Dan berdasarkan data yang diperoleh dari survey awal di PMB Erniati, Am.Keb tahun 2019 terdapat 1129 ibu hamil. Dimana jumlah ibu hamil trimester I (satu) 536 orang, jumlah ibu hamil trimester ke II (dua) 448 orang dan jumlah ibu hamil trimester ke III (tiga) 145. Sedangkan tahun 2020 periode Januari sampai dengan Mei 63 orang.

Tujuan peneliti melakukan penelitian ini adalah untuk mengetahui pengaruh pijat perineum selama masa kehamilan terhadap kejadian rupture perineum di PMB Ida Iriani, S.SiT dan PMB Erniati, Am.Keb.

\section{METODE}

Jenis Penelitin yang digunakan adalah penelitian kuantitatif atau quantitatif design dengan pendekatan desain quasi eksperimen (Polit \& Bec, 2014). Desain quasi eksperimen ini yang digunakan dalam bentuk Post Tes Only Control Group Design.

Lokasi penelitian dilakukan di PMB Ida Iriani, S.SiT dan PMB Erniati, Am.Keb Kabupaten Aceh Utara pada 25 Juni s/d 30 September 2020. Populasi dalam penelitian ini adalah seluruh ibu hamil yang memasuki Timester III dengan usia kehamilan mulai dari 34 minggu dengan Jumlah seluruh sampel yaitu sebanyak 72 responden dengan masingmasing kelompok sebanyak 36 responden.

Variabel dalam penelitian ini adalah Pijat Perineum dan Ruptur Perineum, metode pengumpulan data untuk melihat perbedaan pengaruh pijat perineum selama masa kehamilan terhadap rupture perineum pada kelompok perlakuan atau intervensi (posttest) 
yang menggunakan uji beda 2 mean dengan analisa statistik Mann Whitney.

HASIL

Tabel 1. Distribusi Frekuensi Umur di PMB Ida Iriani, S.SiT dan di PMB Erniati, Am.Keb Kabupaten Aceh Utara Tahun 2020

\begin{tabular}{|c|c|c|c|c|c|}
\hline \multirow{2}{*}{ No } & \multirow{2}{*}{ Umur } & \multicolumn{2}{|c|}{ Intervensi } & \multicolumn{2}{|c|}{ Kontrol } \\
\hline & & $f$ & $\%$ & $f$ & $\%$ \\
\hline 1 & 17-25 tahun & 20 & 55,5 & 16 & 44,4 \\
\hline 2 & 26-35 tahun & 11 & 30,5 & 11 & 30,5 \\
\hline 3 & $36-45$ tahun & 5 & 13,8 & 9 & 25 \\
\hline & Total & 36 & 100 & 36 & 100 \\
\hline
\end{tabular}

Berdasarkan tabel 1 dapat dilihat bahwa pada kelompok intervensi lebih dari setengah responden $(55,5 \%)$ berusia $17-25$ tahun, dan pada kelompok kontrol kurang dari setengah responden $(44,4 \%)$ berumur antara $17-25$ tahun.

Tabel 2. Distribusi Frekuensi Pendidikan di PMB Ida Iriani, S.SiT dan PMB Erniati, Am. Keb

\begin{tabular}{clcccc}
\hline \multirow{2}{*}{ No } & \multirow{2}{*}{ Pendidikan } & \multicolumn{2}{c}{ Intervensi } & \multicolumn{2}{c}{ Kontrol } \\
\cline { 3 - 6 } & & $\boldsymbol{f}$ & $\mathbf{\%}$ & $\boldsymbol{f}$ & $\mathbf{\%}$ \\
\hline 1 & Dasar & 8 & 22,2 & 9 & 25 \\
\hline 2 & Menengah & 17 & 47,2 & 15 & 41,6 \\
\hline 3 & Tinggi & 11 & 30,5 & 12 & 33,3 \\
\hline & Total & $\mathbf{3 6}$ & $\mathbf{1 0 0}$ & $\mathbf{3 6}$ & $\mathbf{1 0 0}$ \\
\hline
\end{tabular}

Dari table 2 dapat dilihat bahwa pada kelompok intervensi kurang dari setengah responden $(47,2 \%)$ memiliki pendidikan menengah, dan pada kelompok kontrol lebih dari sepertiga responden $(41,6 \%)$ juga memiliki pendidikan menengah.

Dari table 3 dapat dilihat bahwa pada kelompok intervensi lebih dari dua pertiga responden $(69,4 \%)$ yang tidak bekerja, dan pada kelompok kontrol kurang dari dua pertiga responden juga tidak bekerja.
Tabel 3. Distribusi Frekuensi Pekerjaan di PMB Ida Iriani, S.SiT dan BPM Erniati, Am.Keb

\begin{tabular}{rrrrrr}
\hline \multirow{2}{*}{ No } & \multirow{2}{*}{ Pekerjaan } & \multicolumn{2}{c}{ Intervensi } & \multicolumn{2}{c}{ Kontrol } \\
\cline { 3 - 6 } & & $\boldsymbol{F}$ & $\boldsymbol{\%}$ & $\boldsymbol{f}$ & $\boldsymbol{\%}$ \\
\hline 1 & Bekerja & 11 & 30,5 & 14 & 38,8 \\
\hline 2 & Tidak Bekerja & 25 & 69,4 & 22 & 61,1 \\
\hline \multicolumn{2}{r}{ Total } & $\mathbf{3 6}$ & $\mathbf{1 0 0}$ & $\mathbf{3 6}$ & $\mathbf{1 0 0}$ \\
\hline
\end{tabular}

Tabel 4. Distribusi Frekuensi Paritas Ibu di PMB Ida Iriani, S.SiT dan PMB Erniati, Am. Keb

\begin{tabular}{cccccc}
\hline \multirow{2}{*}{ No } & \multirow{2}{*}{ Paritas } & \multicolumn{2}{c}{ Interfensi } & \multicolumn{2}{c}{ Kontrol } \\
\cline { 3 - 6 } & & $\boldsymbol{F}$ & $\boldsymbol{\%}$ & $\boldsymbol{f}$ & $\mathbf{\%}$ \\
\hline 1 & Primipara & 16 & 44,4 & 18 & 50 \\
\hline 2 & Multipara & 13 & 36,1 & 10 & 27,7 \\
\hline 3 & $\begin{array}{l}\text { Grande } \\
\text { multipara }\end{array}$ & 7 & 19,4 & 8 & 22,2 \\
\hline & Total & $\mathbf{3 6}$ & $\mathbf{1 0 0}$ & $\mathbf{3 6}$ & $\mathbf{1 0 0}$ \\
\hline
\end{tabular}

Dari table 4 dapat dilihat bahwa pada kelompok intervensi kurang dari setengah responden $(44,4 \%)$ yang primipara, dan pada kelompok kontrol dari setengah responden $(50 \%)$ juga yang primipara.

Tabel 5. Distribusi Frekuensi Ruptur Perineum di PMB Ida Iriani, S.SiT Dan PMB Erniati, Am.Keb

\begin{tabular}{cccccc}
\hline \multirow{2}{*}{ No } & $\begin{array}{c}\text { Rupture } \\
\text { Perineum }\end{array}$ & \multicolumn{2}{c}{ Intervensi } & \multicolumn{2}{c}{ Kontrol } \\
\cline { 3 - 6 } & $\boldsymbol{F}$ & $\mathbf{\%}$ & $\boldsymbol{f}$ & $\mathbf{\%}$ \\
\hline 1 & Tingkat I & 6 & 16,6 & 16 & 44,4 \\
\hline 2 & Tingkat II & 4 & 11,1 & 12 & 33,3 \\
\hline 3 & Tingkat III & 0 & 0 & 2 & 5,5 \\
\hline 4 & Tingkat IV & 0 & 0 & 0 & 0 \\
\hline 5 & Tidak & 26 & 72,2 & 6 & 16,6 \\
\hline \multirow{2}{*}{ Total } & $\mathbf{3 6}$ & $\mathbf{1 0 0}$ & $\mathbf{3 6}$ & $\mathbf{1 0 0}$ \\
\hline
\end{tabular}


Dari table 5 dapat dilihat bahwa pada kelompok intervensi kurang dari dua tiga perempat responden $(72,2 \%)$ tidak mengalami rupture perineum, sedangkan pada kelompok kontrol kurang dari setengah responden $(44,4 \%)$ yang mengalami rupture perineum.

Tabel 6. Pengaruh Pijat Perineum Selama Masa Kehamilan Terhadap Rupture Perineum di PMB Ida Iriani, S.SiT Dan BPM Erniati, Am.Keb Pijatan

\begin{tabular}{ccccccc}
$\begin{array}{l}\text { Perineum } \\
\text { Dipijat }\end{array}$ & n & Mean Rank & Median & Min & Max & Pvalue \\
\cline { 1 - 5 } Tidak Dipijat & 36 & 45,42 & 2,00 & 1 & 2 & 0,000
\end{tabular}

Berdasar tabel 6 maka dapat diketahui nilai mean rank dipijat 45,42, median 2,00, nilai minimal 1 , maksimal 2 , sedangkan mean rank tidak dipijat adalah 27,58 , median 1,00 , minimal 1, maksimal 2. Nilai Pvalue 0,000. Hasil penelitian ini menunjukkan bahwa ada hubungan antara dipijat dengan tidak dipijat terhadap terjadinya ruptur perineum.

\section{PEMBAHASAN}

Berdasarkan hasil penelitian yang didapat selama melakukan pijat perineum antara kelompok intervensi dan kelompok kontrol dengan jumlah sampel 72 responden, masingmasing kelompok 36 responden dengan menggunakan uji mann whitney maka didapat nilai mean rank kelompok intervensi 45,42 dan kelompok kontrol 27,28 dengan nilai pvalue 0,000 yang artinya ada pengaruh pijat perineum terhadap ruptur perineum.

Hasil penelitian ini sejalan Astuti, Harmiati dan Pujianto (2020), menunjukkan hasil dari 18 responden yang diberikan perlakuan pijat perineum nilai mean rank 12,33. Hasil dari 18 responden yang diberikan perlakuan supercrowning nilai mean rank 24,67. Hal ini menunjukkan bahwa nilai mean rank pijat perineum lebih sedikit artinya pijat perineum lebih efektif mencegah ruptur perineum dibandingkan dengan supercrowning. Hasil penelitian yang sama dilakukan oleh Savitri, Ermawati, Yusefni
(2015) bahwa kejadian ruptur perineum pada kelompok intervensi setelah dilakukan pemijatan perineum hanya $21,4 \%$ sementara pada kelompok kontrol $71,4 \%$ dengan hasil $p$ $=0,02(<0,05)$.

Hasil penelitian ini didukung Mutmainah, Yuliasari dan Mariza dalam penelitian pencegahan rupture perineum pada ibu bersalin dengan pijat perineum dengan hasil hasil penelitian didapatkan $p$-value = 0,032 ( $\mathrm{p}$-value $<\alpha=0,05$ ) yang berarti ada pengaruh pijat perineum terhadap pencegahan rupture perineum pada ibu bersalin di BPS Dwi Lestari Natar Lampung Selatan Tahun 2018. Hasil penelitian ini sejalan Anggraini dan Martini (2015).

Hasil uji bivariat yaitu hasil analisis bivariat hubungan pijat perineum dengan robekan jalan lahir di BPM Metro Selatan Kota Metro Tahun 2015, diperoleh p-value sebesar 0,000. Nilai ini jika dibandingkan dengan harga $\alpha=0,05$ maka pvalue $<0,05$ yang berarti bahwa ada hubungan antara pijat perineum dengan kejadian robekan jalan lahir di BPM Metro Selatan Kota Metro Tahun 2015.

Manfaat yang bisa didapatkan setelah melakukan pijat perineum yaitu mencegah terjadinya ruptur perineum maupun episiotomi. Pijat perineum juga dapat meningkatkan aliran darah, melunakkan jaringan di sekitar perineum ibu dan membuat elastis semua otot yang berkaitan dengan 
proses persalinan termasuk kulit vagina. Saat semua otot-otot itu menjadi elastis, ibu tidak perlu mengejan terlalu keras cukup pelanpelan saja bahkan bila prosesnya lancar ruptur pada perineum tidak terjadi dan vagina tidak perlu dijahit (Choirunissa \& Han, 2019).

Mehran (2016), mekanisme pijat perineum dapat mengurangi derajat ruptur perineum yaitu dengan memberikan pijatan, maka aliran darah akan lancar dan nutrisi otot sekitar perineum semakin banyak terpenuhi sehingga menjaga kekenyalan dan keelastisitasan otot. Dengan melakukan gerakan menggosok akan membuat suhu otot meningkat, sehingga meningkatnya produksi ATP, dimana ATP ini digunakan untuk membantu ion-ion Ca++ dipompa masuk kembali kedalam reticulum sarkoplasma dengan cara traanspor aktif, sehingga kerja troponin dan tropomiosin kembali aktif guna menghambat reaksi aktin-myosin dalam kata lain, aktyn-myosin tidak dalam keadaaan aktif, Kemudian otot akan relaksasi (mengendur/menjadi lentur).

Indivara (2009) Pijat perineum adalah teknik memijat perineum yang dilakukan saat hamil atau 2 minggu sebelum persalinan yang bermanfaat untuk melembutkan jaringan ikat, melancarkan peredaran darah, relaksasi. Tindakan ini akan mengurangi terjadinya rupture perineum, episiotomi dan nyeri karena jahitan episiotomy. Sedangkan menurut Ishak (2012), pijat perineum dapat menciptakan rasa rilkes dan memberikan ketenangan pada ibu, menyiapkan mental ibu terhadap tekanan dan regangan pada perineum di kala kepala bayi akan keluar.

Menurut asumsi peneliti, peneliti menyimpulkan bahwa dari hasil uji mann whitney dengan nilai pvalue $0,000<0,05$ yang artinya ada pengaruh pijat perineum terhadap ruptur perineum, pijat perineum adalah teknik memijat perineum yang dilakukan saat hamil atau 2 minggu sebelum persalinan yang bermanfaat untuk melembutkan jaringan ikat, melancarkan peredaran darah, relaksasi. Pijat perineum dapat meningkatkan aliran darah dan nutrisi otot sekitar perineum semakin banyak terpenuhi sehingga menjaga kekenyalan dan keelastisitasan otot dan melunakkan jaringan di sekitar perineum ibu dan membuat elastis semua otot yang berkaitan dengan proses persalinan termasuk kulit vagina.

\section{KESIMPULAN}

Berdasarkan penelitian yang telah dilakukan oleh peneliti terhadap 72 responden dengan dua kelompok yaitu kelompok intervensi dan kelompok kontrol masingmasing kelompok 36 responden dengan penelitian yang berjudul "Pengaruh PijatPerineum Selama Masa Kehamilan Terhadap RupturePerineum di PMB Ida Iriani, S. SiT dan PMB Erniati, Am.Keb Kabupaten Aceh Utara", maka dapat diperoleh hasil karakteristik responden sebagai berikut : Pada kelompok intervensi di dapatkan hasil 26 responden $(72,2 \%)$ yang tidak mengalami rupture perineum. Pada kelompok kontrol di dapatkan hasil 14 $(44,4 \%)$ responden yang mengalami rupture perineum. Ada pengaruh pijat perineum selama masa kehamilan terhadap rupture perineum dengan nilai Pvalue 0,000 .

\section{UCAPAN TERIMAKASIH}

Terimakasih kepada Suami dan anakanak perserta kedua orangtua dan keluarga yang terus memberikan dukungan moril serta materil untuk peneliti. Kepada seluruh pihakpihak yang terlibat dalam proses penelitian yang tidak dapat penliti sebutkan satu persatu. Terimakasih kepada pihak jurnal PREPOTIF yang sudah memfasilitasi peneliti untuk mempublikasi hasil penelitian agar dapat lebih bermanfaat. 


\section{DAFTAR PUSTAKA}

Angraini, Y \& Martini. (2015). Hubungan Pijat Perineum Dengan Robekan Jalan Lahir Pada Ibu Bersalin Primirapa Di BPM Kecamatan Metro Selatan : Kota Metro

Anwar, H.(2014). https://www.statistikian.co m. (Diakses Pada Tanggal 19 Mei 2020).

Choirunissa, R \& Han, H. (2019). Pengaruh Pijat Perineum Terhadap Derajat Robekan Perineum Pada Ibu Hamil Primigravida Di BPM Ny I. Jurnal Ilmiah Kesehatan, Vol (11). Jawa Barat

: Cipageran Cimahi Utara Kota Cimahi. -(2019).Pengaruh Pijat Perineum Terhadap Derajat Robekan Perineum Pada Ibu Hamil Primigravida Di BPM Ny I. Jurnal Ilmiah Kesehatan, Vol (11). Jawa Barat : Cipageran Cimahi Utara Kota Cimahi.

Dharma, K. (2015). Metodologi Penelitian Keperawatan. Jakarta timur : CV. Trans Info Media.

Data Dinkes Kabupaten Aceh Utara. (2018). Pofil DataKematian IbuAceh Utara.

Data Dinkes Provinsi Aceh. (2018). Pofil DataKematian IbuProvinsi Aceh.

Data PMB Ida Iriyani, S.SiT. (2020). Data Awal Ibu Bersalin. Kabupaten Aceh Utara.

Fatimah, \& Lestari, P .(2019) Pijat Perineum Menguragi Rupture Perineum Untuk kalangan Umum Ibu Hamil dan Mahasiswa Kesehatan. Yogyakarta : Pustaka Baru Press.

------(2019) Pijat Perineum Menguragi Rupture Perineum Untuk kalangan Umum Ibu Hamil dan Mahasiswa Kesehatan. Yogyakarta : Pustaka Baru Press.
Grove, S. K., Burns, N., \& Gray, J. R. (2013). Understanding nursing research: Building an evidence-based practice. Elsevier Health Sciences.

Notoatmodjo, 2012. Metodologi Penelitian Kesehatan. Jakarta: Rineka Cipta.

Handayani, i, \& Sugiarsih,U. (2018). Efektifitas Pemijatan Perineum Pada Primigravida Terhadap Kejadian Laserasi Perineum. Jurnal Penelitian Kesehatan Suara Forikes, Vol (9) $\mathrm{No}(2)$

Hurlock, E. B. 2011. Psikologi Perkembangan : Suatu Pendekatan Sepanjang Rentang Kehidupan, Erlangga, Jakarta.

Hidayati R, Zahariah Sultanah. 2018. http://www.akbidplus-drsoebandi.com. (Diakses Tanggal 20 Oktober 2020).

Ishak,S. Ft Physio. (2012). Buku Petunjuk Pelaksanaan Massage Perineum pada Ibu Hamil. Jakarta : EGG.

Indivara. (2009). Panduan Senam Hamil. Jakarta : Rineka Cipta.

Lesari, U. (2016). Ulestari95./2016/03/makala h-ruptur-perineum.html (Diakses Pada Tanggal 18 Juni 2020).

Mehran. (2016). Reducing perineal trauma through perineal massage with vaseline in second stage of labour. Maternal Fetal Medicine.

Nuryawati, L, \& Yuwansyah, Y. (2019). Pengaruh Pijat Perineum Terhadap Derajat Robekan Perineum Pada Ibu Hamil Primigravida >34 Minggu Di Wilayah Kerja UPTD Pukesmas DTP Maja. Jurnal Ilmiah IndonesiaI, (10) : halaman. Doi/ISSN.

(2019). Pengaruh Pijat Perineum Terhadap Derajat Robekan Perineum Pada Ibu Hamil Primigravida >34 Minggu Di Wilayah Kerja UPTD 
Pukesmas DTP Maja. Jurnal Ilmiah IndonesiaI, (10) : halaman. Doi/ISSN.

Polit, D.F, \& Beck, C.T. (2014). Essentials of nursing

research: Appraising evidence for nursing practice (8th ed.). Philadelphia, PA : Wolters Kluwer.

Rochmayanti, S \& Ummah, K. (2019). Pijat Perineum Selama Kehamilan Terhadap Rupture Perineum. Yogyakarta : Jakad Media Publishing.

Singalingging, M \& Sikumbang, S. (2018) Terjadinya Rupture Perineum Pada Ibu Bersalin. Medan : RSU Imelda

Savitri. (2015). http://jurnal.fk.unand.ac.id/in dex.php/jka/article/view/204/199.(Diakse s Pada Tanggal 20 Mei 2020).
Savitri, W \& Ernawati. (2015). Pengaruh Pemijatan Perineum pada Primigravida terhadap Kejadian Ruptur Perineum saat Persalinan. Jurnal Kesehatan Andalas. Kota Bengkulu : Bidan Praktek Mandiri

Sulistyawati, Ari dan Nugraheny. (2009). Asuhan Kebidanan Ibu Bersalin. Jakarta: Salemba Medika.

Wulandari. (2014). Pijat Perineum Menguragi Rupture Perineum Untuk kalangan Umum Ibu Hamil dan Mahasiswa Kesehatan. Yogyakarta : Pustaka Baru Press.

Wiknjosastro, H. 2010. Ilmu Kandungan, Yayasan Bina Pustaka Sarwono Prawirohardjo, Jakarta. 